\title{
Obamas udfordringer
}

\section{Steffen Gram}

\section{Obama har leveret varen med fangsten af Osama bin Laden, men kan han også levere, når det gæl- der økonomien?}

Solen skinnede fra Floridas skyfri himmel. Bilen gled gennem Fort Myers, over broen og de to dæmninger mod Sanibel og Captiva Island i Den Mexicanske Golf. Et drømmested for fiskere, naturelskere og turister! Palmer i endeløse rækker langs vejene. Violette blomster overalt. Bag den tropiske bevoksning ligger hoteller, lave blokke med ferieboliger, tennisbaner, golfbaner og swimmingpools.

I en forretning blev jeg hilst med det sædvanlige "How are you today?". "I'm good," svarede jeg. "How can't you be good down here?" replicerede ekspedienten.

Og Florida er et paradis - havde det ikke været for skoven af 'for sale'-skilte! For Florida er mere eller mindre til salg! Tre år efter boligmarkedets sammenbrud og finansverdenens flirt med den totale kollaps er pensionisternes og turisternes Florida i krise.

Boligejere har sendt boliger på tvangsauktion i hundredtusindvis.
Floridas arbejdsløshed var 12 procent ved årsskiftet og 10,6 procent $\mathrm{i}$ maj, dvs. over det nationale gennemsnit på 9,2 procent - når vi er venlige. USA's reelle arbejdsløshed er nærmere de 16 procent, når alle uden arbejde, der gerne vil i arbejde, er talt med.

Guvernøren, Tea Party- og erhvervsmanden uden politisk erfaring Rick Scott, blev valgt i november til at rydde op i statens finansielle kaos, efter en bitter valgkamp, der splittede det Republikanske Parti. I dag er hans 'approval-rating' styrtet til bare 22 procent blandt vælgere, der ser besparelsernes grønthøster køre hen over deres samfund.

Floridas budget stammer primært fra ejendomsskatter. Man da ejendomsmarkedet kollapsede, styrtede skatteprovenuet - og statens indtægter! Nu prøver Rick Scott at spare staten ud af et budget-underskud på 3,6 milliarder dollar ved at skære i offentlige ydelser - fra medicare, over fængselsvæsenet, til skoler - i et 
af de mest konservative budgetter i USA.

\section{Forbitrede vælgere}

Vælgerne er forbitrede. De mister deres boliger og deres job, specielt når det offentlige skærer. Og med jobbet ryger ofte sygesikringen. Den offentlige arbejdsløshedsunderstøttelse varer 26 uger med et maksimumbeløb på 275 dollar om ugen eller små 6.000 kroner om måneden. Det kan man ikke leve for - slet ikke familier, der skal afdrage på boliglån, betale lægeregninger eller sende børn på college. Og Scott prøver at få reduceret perioden for understøttelse til 12 uger. Og turen gennem Fort Myers fortæller hele historien - tomme forretninger, halvfærdige indkøbscentrer, flotte hvælvede indkørsler til nye boligkvarterer, der aldrig er blevet færdige.

Oppe i det køligere nord, i Minnesota, hjemsted for normalt rationelle efterkommere af skandinaviske og nordeuropæiske immigranter, der gerne praler af deres effektive styring af staten, deroppe lukkede det offentlige ganske enkelt fredag d. 1. juli. 20.000 offentlige ansatte stod uden job og løn.

Offentlige kontorer og nationalparker blev lukket. En dommer besluttede, at kun essentielle offentlige funktioner kan holdes kørende det vil sige alt, hvad der vedrører offentlig sikkerhed, en række velfærdsprogrammer, pleje af beboere i of- fentlige institutioner og af indsatte i statsfængsler og helt nødvendige administrative offentlige funktioner.

Da Minnesotas vælgere gik til valg i november sidste år, stemte de for første gang i 40 år et republikansk flertal ind i Minnesotas Kongres men valgte samtidig en demokratisk guvernør, Mark Dayton.

Dayton og det republikanske flertal i Kongressen stod med en overvældende opgave - at lukke underskuddet på fem milliarder dollar i statens budget. De har forhandlet lige siden - og nåede frem til et toårigt budget, hvor guvernør Dayton foreslog offentlige udgifter på 35,8 milliarder dollar over de næste to år, mod republikanernes 34 milliarder.

Men fordelingen og finansieringen af budgettet skilte parterne. Demokraten Mark Dayton ville blandt andet hæve skatterne for Minnesotas to procent rigeste. Republikanerne ville spare sig ud af problemerne.

\section{National debat}

Tonen og holdningerne i debatten er identiske med den nationale debat. "Jeg kan ikke acceptere at Minnesota, hvor borgere med handikap får skåret i den tid, hvor de får pleje ..., så millionærer ikke behøver betale en dollar mere i skat", erklærede guvernør Mark Dayton.

Republikanerne erklærede, at de havde arbejdet på at imødekomme guvernøren. "Desværre har guvernør Dayton valgt at prioritere sin sti- 
ve beskat-og-spender-ideologi snarere end at prioritere borgernes interesser", erklærede republikanernes Amy Koch, præsident for Senatet.

Krisen og debatterne ude i de amerikanske stater er den scene, præsident Barack Obama optræder på. Konfrontationen mellem demokrater og republikanere i Washington er en afspejling af, hvad der sker ude i landet. Og det er vælgerne landet over, der - med afsæt i deres lokale situationer - vælger deres politikere og præsidenten. Det gør de igen til november næste år, hvor det bliver afgjort, om republikanerne når deres mål - at gøre præsident Obama til en fire-års-præsident.

Der er stater med stærke demokratiske traditioner. Andre med stærke republikanske. Og der er sving-stater - hvor hverken demokrater, republikanere eller en specifik præsident-kandidat kan sige: Det er min stat. Den vinder jeg!

Minnesota har tradition som demokratisk stat, der dog blev brudt ved sidste midtvejsvalg, hvor republikanerne som næunt fik flertal i den lokale Kongres for første gang i 40 år. Men Florida er en svingstat. Derfor er Floridas krise Obamas krise. Obama har brug for Florida. Han skal meget gerne vinde Florida, hvis han skal have fire år mere i Det Hvide Hus.

I Florida - som i resten af USA ved de godt, at Obama ikke har skabt krisen. Men de ved også, at de ikke har fået det meget bedre, siden han blev præsident. Og i november sidste år sendte vælgerne landet over Obama og demokraterne en advarsel ved midtvejsvalget til Kongressen i Washington. Demokraterne fik smæk og tabte flertallet i Repræsentanternes Hus - bare to år efter Obamas sejr i 2008, hvor kommentatorer talte om 'demokraternes tidsalder' årtier frem!

Et var, at det republikanske højre og Tea Party-bevægelsen stemte nej til Obama. Noget andet, at venstrefløjen var skuffet over Obama. Det værste for Obama og hans demokrater var, at det politiske centrum, 'the Independents', der afgør præsidentvalgene, stemte nej til demokraterne og til Obama.

De uafhængige demonstrerede, at de havde mistet tilliden til deres intellektuelle præsident, der tilsyneladende hverken havde 'the guts for the political fight' eller evnen til at 'lede'. "He is leading from behind", som kritikerne sagde - og siger.

De ville have resultater. I stedet havde de fået politisk konfrontation, demokratisk arrogance og resultater, der var svære et få øje på.

Præsident Obama havde gennemført en række reformer - redningspakken til bilindustrien, en gennemgribende finansreform, sin ikke særligt populære sundhedsreform, sine hjælpepakker, der skulle forhindre et frit økonomisk fald!

Men han havde solgt sine reformer skidt og havde overladt initiativer og de politiske forhandlinger til 
politikerne i Kongressen. Det føltes, som om Obama havde berøringsangst over for det politiske slagsmål.

\section{Vælgernes straf}

Obama kaldte vælgernes straf en 'shellacking' - en øretæve!

For første gang siden midtvejsvalget i 1982 fik republikanerne flere kvindelige stemmer end mandlige! Ikke siden midtvejsvalget i 1982 stemte så mange katolikker, uafhængige og vælgere over 60 på republikanerne.

Vælgerne under 30 var eneste vælgergruppe opgjort efter alder, der stemte demokratisk - men de udgjorde kun 11 procent af de vælgere, der stemte! Minoriteterne stemte stadig for demokraterne - asiaterne, latinoerne, sorte i overvældende tal, bøsser og lesbiske - men de hvide stemte først og fremmest republikansk. Obama og hans demokratiske flertal i Kongressens to kamre havde ikke bare optrådt arrogant. De havde ikke leveret de kompromiser og resultater, Obama havde lovet! Så vælgerne gav Repræsentanternes Hus til republikanerne. Republikanerne vandt 62 pladser. I Senatet skrumpede demokraternes flertal til et enkelt medlem og to ikke altid trofaste løsgængere!

Republikanerne jublede. Obama erkendte demokraternes nederlag og skiftede taktik! Seks uger efter midtvejsvalgets nederlag, havde han forhandlet tre store reformer igen- nem, før republikanerne kunne tage deres sejr i besiddelse i Repræsentanternes Hus.

Han havde forhandlet et skattekompromis igennem med republikanerne, der tilmed var en maskeret hjælpepakke. Han sikrede Senatets godkendelse af START-aftalen (den strategiske atomnedrustningsaftale) med russerne. Og han fik 'don't ask, don't tell'-lovgivningen fra Clintontiden, der gjorde det muligt for bøsser og lesbiske at tjene i militæret, såfremt de holdt deres seksualitet skjult, afviklet i Senatet og vedtaget en ny lov, hvor alle amerikanere kan tjene i militæret, også åbenlyst homoseksuelle.

Han havde indfriet et gammelt valgløfte og signaleret, at han stadig satsede på menneskerettigheder trods sit tilbagetog i spørgsmålet om lukningen af Guantanamo!

Barack Obama havde demonstreret den politiske handlekraft, hans tilhængere og amerikanerne havde savnet. Men - det er mere end et halvt år siden!

Siden den nye Kongres blev taget i ed i januar, har Kongressen - og lovgivningsarbejdet - været nærmest lammet, og Obamas hjemlige dagsorden ser ud til at være gået i stå.

De positive økonomiske tendenser fra sidste kvartal i 2010 og første i 2011 er gået i stå. Amerikanerne er bekymrede, optimismen tonet ned og troen på at man kan arbejde sig ud af problemerne på sædvanlig amerikansk vis, forsvundet. 
Der skal noget mere og andet til noget større. Spørgsmålet er bare, hvem skal lede vejen - hvis politikerne ikke kan eller vil?

Eller som kommentatoren Thomas Friedman formulerede det $\mathrm{i}$ New York Times i juni: "There is something crazy about what is going on in our country today. Our fiscal conditions continues to be on an unsustainable path..... unemployment is creeping upward and basically our two parties are telling us that they will not make the reforms that we know are necessary because it would involve too much pain and could imperil their chances of winning the presidency in 2012".

\section{Valget i 2012}

Det politiske spil handler fra nu af om valget i 2012. Bliver Barack Obama en 'one-term-president', eller sikrer han sig genvalg som USA's historiske første sorte præsident?

Barack Obama er en intellektuel præsident. Han dyrker inspirationen. Han elsker at tale til de unge, til fremtiden. Hans visioner for Amerika handler om social retfærdighed, om at forbedre uddannelserne, gøre USA mere uafhængig af omverdenens energiforsyninger, sikre USA som verdens stærkeste og mest indflydelsesrige magt i en ny verden, hvor en betydelig del af USA's velstand og velfærd ikke bliver afgjort i USA, men i de nye økonomier i Kina, Indien, Brasilien etc.
Han er også cool! Det var cool, at sende kommandosoldater ind i Pakistan, skyde Osama bin Laden og vende hjem med en skatkiste af informationer fra bin Ladens compound om al-Qaeda. Vel at mærke, efter at Obamas egen forsvarsminister havde advaret mod angrebet. Robert Gates ville bombe bin Ladens bolig. Obamas popularitet voksede dramatisk - for en stund. Det var også $\mathrm{cool}$ at fordoble antallet af amerikanske styrker i Afghanistan allerede i 2009 trods valgløfter om at afslutte krigene.

Men i de sidste måneder har amerikanerne måttet lede efter både den intellektuelle og den cool præsident! De har ventet på ham og hans visioner for og løsninger på USA's budgetproblemer og i kampen om låneloftet, der i skrivende stund stadig er uløst og truer med at udløse en vældig politisk konflikt med eventuelt uoverskuelige konsekvenser for de internationale finansmarkeder.

Hans udfordring er at gøre sine løsninger, sin politik og sine visioner troværdige på den korte bane frem til næste valg i november 2012. Kan han samtidig gøre republikanernes løsninger utroværdige, asociale og skadelige for USA, vil han hjælpe sin sag. Men grundlaget for valgkampens emner er dystert!

Samfundets gæld er ifølge meningsmålinger amerikanernes største bekymring. De frygter gælden og dens begrænsning af økonomien, 
beskæftigelsen, på hverdagen og næste generations muligheder for at skabe sig en bedre fremtid end forældrenes.

Gælden er blevet et dramatisk emne i den politiske kamp, fordi det ellers trivielle spørgsmål om at hæve den amerikanske stats låneloft er blevet et bittert politisk spørgsmål, der illustrerer de to partiers politiske - og ideologiske - forskelle i en tid, hvor det konservative Amerika bliver endnu mere konservativt. Demokraterne vil hæve skatterne og investere sig ud af krisen. Republikanerne vil spare sig ud af krisen. $\mathrm{Og}$ alle er klar over, at der skal tages beslutninger, der vil gøre ondt!

Det amerikanske låneloft er på 14,3 tusinde milliarder dollar. Forhandlerne har i skrivende stund en snæver deadline. USA når loftet den 2. august - men allerede 22. juli skulle foreligge en lovgivning for, hvordan loftet bliver hævet. (Det lykkedes den 31. juli at nå til enighed om en aftale, som efterfølgende blev vedtaget i Kongressens to kamre i løbet af den 1. og 2. august. Red).

Der er blevet forhandlet sommeren over. Vicepræsident Biden forhandlede med en lille gruppe fremtrædende republikanere. Det endte i sammenbrud, og Obama trådte selv ind i forhandlingerne. Republikanerne stillede som betingelse for forlig, at en stigning i låneloftet udlignes med besparelser og at skatterne ikke hæves. Demokraterne vil hæve skatter for de allermest velhavende, lukke huller i skattelovgivningen, fx huller for ejere af private jetfly, og så vil regeringen eliminere subsidier til olie- og gasindustrien.

Parterne har identificeret besparelser på omkring et tusind milliarder dollar over de kommende ti år, ca. 100 milliarder om året, der primært vil ramme regeringsprogrammer og -ydelser. Så mangler parterne omkring et tusind milliarder mere - og det er svært at se, hvor de skal komme fra.

Demokraterne vil protestere voldsomt, når - eller hvis - der kommer et kompromis. Den progressive fløj af partiet vil skælde Obama ud og hævde, at han har givet køb på demokratiske kerneværdier. Det vil Obama overleve.

Republikanerne, derimod, kan få svært ved at få stemmer fra egne rækker til et kompromis i Repræsentanternes Hus. Med Tea Party-bevægelsens indmarch ved midtvejsvalget sidste november fik mere traditionelle republikanere svækket deres politiske råderum.

Tea Party-bevægelsen er imod såvel en hævning af låneloftet som skattestigninger for at modvirke nedskæringer. Derfor kan republikanernes formand i Repræsentanternes Hus, John Boehner, komme til at stå i den vanskelige situation, når det muliges kunst skal føres ud i livet, at han kommer til at vedtage et kompromis om låneloftet med demokratiske stemmer. 


\section{Kommende budgetter}

Kampen om gælden handler også om statens budgetter. I skrivende stund er forbundsregeringens budget kun på plads få måneder endnu. Så skal demokrater og republikanere igen til at slås, nu om budgettet for 2012. Budgetforhandlinger vil afhænge meget af udfaldet af konflikterne omkring låneloftet, men det er givet, at de bliver barske og et nyt budget vil formentlig blive brudt op i en række kortvarige budget-forlig. (Aftalen indgået den 31. august indebærer også besparelser over de næste ti år på ca. 1000 mia. dollar. Red).

Obama har allerede sagt, at der skal skæres - også i forsvarsbudgettet. Og for første gang i mange år er der sprækker i republikanske rækker. En række republikanere er parate til at skære i forsvaret - og det afspejler en ny trend blandt republikanere, en voksende isolationisme!

Blandt konservative republikanere kører en ny debat om USA's internationale rolle, om rimeligheden $i$ at føre to krige, om at finansiere genopbygning af specielt Afghanistan samtidig med at økonomiske, sociale og sundhedsmæssige fundamenter smuldrer hjemme i USA. En debat, der også foregår blandt demokrater - og som fik Obama til i juni at erklære, at det er på tide med "some nation-building here back home"!

Men de fundamentale økonomi- ske uoverensstemmelser mellem demokrater og republikanere handler om stor regering kontra mindre regering, om højere skatter kontra lavere skatter, om statens indflydelse på og kontrol med USA's svulmende social- og sundhedssektor.

Obama har allerede fået vedtaget sin Obama-care, der bliver rullet ud over USA i de kommende år og for alvor vil kunne mærkes fra 2014.

Republikanerne har med Paul Ryan, medlem af Repræsentanternes Hus fra Wisconsin, leveret et modspil til Obamas sundhedslovgivning - et forslag, der minder om Obamas tanker om at etablere 'exchanges', hvor ældre amerikanere kan shoppe omkring og finde de forsikringer, der passer dem bedst.

Men der er dramatiske forskelle på de to programmer, specielt når det handler om, hvilke goder og ydelser private forsikringspolicer vil yde, efterhånden som tiden går.

Paul Ryans omfattende forslag blev hurtigt en skydeskive for hans demokratiske modstandere. De beskyldte ham og republikanerne, der støttede hans planer, for at ville ødelægge fundamenterne i ældre amerikaneres medicare og medicaid.

Det kan være, at amerikanerne ikke forstod Obama-care. Men de forstår, når nogen vil udhule de relativt beskedne offentlige programmer, der findes for de ældre. Obama-care er relativt upopulær, fordi reformen blev solgt dårligt. Ryans plan er direkte upopulær. I juni var 
35 procent af de adspurgte i meningsmålinger helt imod Ryans sundhedsreform, mens bare 32 procent var lidt eller helt for hans planer. Det betyder også, at Paul Ryan, der har været et sikkert republikansk medlem af Repræsentanternes Hus i 12 år, nu står foran en barsk valgkampagne, hvor vælgerne langt fra er overbeviste om hans planer - og måske vil dumpe ham.

\section{Obamas møllesten}

Det sendte chokbølger over USA, da ledighedstallene kom for maj. Arbejdsløsheden var steget igen. Optimismen fra begyndelsen af første kvartal blev til noget nær depression. Arbejdsløsheden er den gængse tommestok her, når man vil måle en præsidents chancer for at blive genvalgt. Og arbejdsløsheden er en møllesten om halsen på Barack Obama. En arbejdsløshed på 9,2 procent gør det svært for en præsident at blive genvalgt - men heller ikke umuligt!

Sidste år faldt ledigheden svagt. Det samme skete de første måneder i år. Så kom de svage tal for vækst og ledighed i april og de helt elendige tal for maj måned, hvor ledigheden igen steg til over 9 procent

Regner vi den økonomiske vækst ind i ledighedstallene, er det svært at se, hvordan ledigheden vil falde mere end svagt i det kommende år. Væksten i 2011 vil ligge lige på eller under de tre procent, der skal til for at fastholde beskæftigelsen. Væksten for 2012 bliver ikke meget højere. Der bliver derfor næppe tale om forbedring af ledigheden.

Her i USA, hvor kommentatorer elsker at gøre alt op i tal og statistikker, er det ved at blive en sandhed, at ingen præsident er blevet genvalgt med en arbejdsløshed på over 7,2 procent siden præsident Roosevelt. Han blev genvalgt i 1936 med en arbejdsløshed på 16,6 procent og i 1940 med 14,6 procent.

I moderne tid blev præsident Reagan genvalgt i 1984 med den højeste ledighed siden Roosevelt - 7,2 procent. Men dengang - hvor jeg dækkede valget som korrespondent for DR - var vælgerne overbeviste om, at Reagan ikke havde skabt arbejdsløsheden. Den var, fortalte traditionelle demokratiske arbejdere på blokadevagt uden for en fabrik i Rockford, Illinois, skabt af den demokratiske præsident Carter - der tilmed var blevet ydmyget af først Sovjetunionen, der invaderede Afghanistan, og derefter mullahstyret i Iran, der tog amerikanske diplomater som gidsler.

Amerikanske vælgere var ikke i tvivl: De elskede (og nogle elskede at hade) Reagan og hans optimistiske 'It's Morning in America'-budskab.

Ledigheden er og bliver et problem for Obama - specielt hvis vælgerne ikke er overbeviste om, at hans løsninger er de rigtige. Og det er vælgerne ikke i dag. Men de ved 
også, at USA’s økonomiske uføre ikke blev skabt af Obama. Det blev skabt af Bush, republikanerne og to krige, der slugte overskuddet på statens finanser fra Clinton, og den kapital USA lånte under Bush.

I dag viser økonomiske modeller hvis de holder - at væksten i det næste halvandet år vil tage til (beskedent), at ledigheden vil falde (beskedent) - og at det bliver op til Obama at overbevise vælgerne om, at USA er på ret kurs i en lang sej kamp, at republikanernes løsninger er utroværdige og asociale, og at ikke mindst han, Barack Obama, kan skabe de kompromiser og dermed resultater, som vælgerne vil have, specielt de uafhængige vælgere i centrum, der går mere efter resultater end ideologi.

\section{USA i verden}

Den amerikanske debat handler først og fremmest om 'the state of the union', hvordan står det til i USA. Og det står ikke specielt godt til. Derfor blev krigene i Irak og Afghanistan stort set ikke nævnt under valgkampen ved midtvejsvalget for et lille år siden. De var ikke en del af valgkampens emner eller af vælgernes bekymringer - med mindre de havde slægtninge i krig.

Derfor har debatten om USA's internationale rolle skiftet karakter. Efter 11. september 2001 og under Bush handlede debatten om USA's engagement i verden om, hvordan man bekæmpede al- Qaeda, Osama bin Laden og terrorismen.

Med bekymring over nationens langsigtede økonomiske helbred, bliver USA's internationale rolle oftere og oftere anskuet ud fra økonomiske vinkler i den offentlige debat, end ud fra USA's kortsigtede og langsigtede globale interesser. $\mathrm{Og}$ der spirer en ny isolationisme, også blandt republikanerne, men det $g ø r$ ikke den internationale menu på Obamas tallerken mindre.

Essensen er, at USA er i økonomiske vanskeligheder, og at Obama skal finde den rigtige balance mellem USA's økonomiske styrke og USA's internationale engagement. Men det er ikke noget, der optager vælgerne specielt meget. Amerikanske præsidenter bliver ikke valgt på deres internationale succeser!

$\mathrm{Nu}$ vil belastningen af det amerikanske budget blive mindre, når krigen i Irak nærmer sig sin afslutning. Det hjælper på den offentlige mening. Efterhånden som amerikanske styrker bliver hentet hjem fra Afghanistan, først de 33.000 mand der udgjorde Obamas 'surge', vil drænet i de offentlige kasser også falde - og hjælpe på den offentlige mening. For krigene er upopulære. Og efter likvideringen af Osama bin Laden vokser argumenterne for, at den krig nu er slut, som man tog af sted for at vinde - krigen mod al-Qaeda og mod terror.

Obamas nye forsvarsminister, Leon Panetta, sagde ved sin tiltræ- 
delse i juli, at hans opgave er at reducere de amerikanske forsvarsudgifter, uden at det påvirker USA's evne til at projicere sine interesser verden over.

Det vil betyde nye våbensystemer, fx nye generationer af de droner pilotløse fly bestykket med missiler som al-Qaedas ledere erkendte virkelig svækkede deres organisation. Og det vil betyde eliminering af dyre våbenprogrammer og baser, ikke bare i USA - også oversøiske.

For Obama har det været afgørende at ændre det billede af USA, som omverdenen havde fået under George W. Bush som en 'bully', man enten er for eller imod. Det var baggrunden for Obamas tale i Kairo til den muslimske verden kort efter sin indsættelse i Det Hvide Hus.

\section{Først til Kina}

Det var intet tilfælde, at Hillary Clinton tog til Kina på sin første rejse som udenrigsminister - og intet tilfælde, at amerikansk fokus først og fremmest er rettet mod Asien, mod Kinas voksende indflydelse. De mindre asiatiske nationer mærker Kinas stadig mere bastante tilstedeværelse med kinesiske baser, der skyder op, havne, der bliver overtaget af kineserne i en stadig større radius fra Kina. Og det går ikke unoteret i Washington, at USA's popularitet vokser i Asien i takt med, at bekymringen for Kinas ambitioner vokser.

Etablering af og en konstant juste- ring af en ny balance i forholdet mellem USA og Kina bliver Obamas store udfordring - i en eventuel anden præsidentperiode - og det helt centrale element i Obamas langsigtede strategiske politik, der skal sikre USA's globale position.

Europæerne er stadig vigtige som leverandører af politisk og moralsk legitimitet i FN og militær opbakning. Obama talte sine store ord på sin seneste rejse til Storbritannien, Frankrig og Polen. Men selv om Obama ser rationalet for, at Europa stadig spiller en betydelig rolle, så er det også klart, at han ikke har mange af sine forgængeres tætte bånd til Europa. Han og hans administration døjer med, at Europa har svært ved at tackle de økonomiske kriser i Grækenland, Irland, Portugal og Spanien. Den træge europæiske handlekraft svækker europæernes slagkraft som allierede - og truer i disse måneder det vaklende amerikanske økonomiske opsving.

Det har været vigtigt for Obama at få en udvikling i gang i konflikten mellem israelere og palæstinensere. I modsætning til forgængerne forsøgte han tidligt at presse en forhandling i gang, men forgæves!

Obamas insisteren på at få Israels ministerpræsident Benjamin Netanyahu til at standse udviklingen af bosættelser på den besatte Vestbred har givet både israelere og palæstinensere en barriere, begge parter kan bruge - og har brugt.

$\mathrm{Nu}$ står Obama med en af sine 
største udfordringer på kort sigt. Han er ydmyget af Netanyahu og skal afværge et diplomatisk nederlag i FN til september. Efter den tvivlsomme forsoning mellem det palæstinensiske selvstyre på Vestbredden og Hamas i Gaza, risikerer USA at stå over for kravet om FN's generalforsamlings godkendelse af en palæstinensisk stat. Sker det, risikerer USA at stå diplomatisk isoleret på Israels side og sætte en betydelig del af den prestige og goodwill over styr, som Obama og hans sikkerhedspolitiske team har bygget op.

Med de iranske bestræbelser på formentligt - at udvikle kernevåben, med de pakistanske institutioner truede og med et pakistansk-amerikansk forhold, der nærmest bygger på mistillid, med den arabiske verden i et opbrud, vi ikke kender resultaterne af, har USA's regering tallerkenen fuld. Dertil kommer den underliggende debat, som Obama og hans team også er ved at tage hul på: hvordan udvikler USA en national sikkerhedsstrategi, der bygger på USA's egen styrke og kvaliteter?

I foråret skrev Mr. Y - pseudonym for kaptajn Porter og Oberst Mark Mykleby fra marineinfanteriet - deres tankevækkende A National Strategic Narrative - en opfølgning af
George Kennans berømte papir, der gjorde 'containment' til fundamentet i den amerikanske strategi over for Sovjetunionen. Et papir som deres bliver hverken skrevet eller offentliggjort uden politisk accept fra deres topledelse. Mr. Y argumenterede, at USA tager fejl i sine prioriteter, at statens budget er forkert sat sammen, at amerikanerne bruger deres ressourcer forkert, og at USA har overreageret i krigen mod terror. De skrev også - hvad Obama bruger som tema i sine budskaber at USA investerer for lidt i sine kvaliteter, i sin ungdom, i sin talentmasse, i sin konkurrenceevne, i sin fremtid, og at USA skal se sin styrke og indflydelse på den globale scene, ikke gennem sin evne til at knuse trusler militært, men gennem inspiration, sin konkurrenceevne og åbenhed.

Til november næste år vil vi vide, om Obama har magten, kløgten og den politiske stamina til at overbevise vælgerne om, at han og landet er på rette vej - eller om republikanerne vil være i stand til at gøre Obama til en 'one-period-president'!

Steffen Gram er Danmarks Radios korrespondent $i$ USA. 